\title{
Language and Culture
}

\author{
Claire Kramsch
}

This paper surveys the research methods and approaches used in the multidisciplinary field of applied language studies or language education over the last fourty years. Drawing on insights gained in psycho- and sociolinguistics, educational linguistics and linguistic anthropology with regard to language and culture, it is organized around five major questions that concern language educators. The first is: How is cultural meaning encoded in the linguistic sign? It discusses how the use of a symbolic system affects thought, how speakers of different languages think differently when speaking, and how speakers of different discourses (across language or in the same language) have different cultural worldviews. The second question is: How is cultural meaning expressed pragmatically through verbal action? It discusses the realization of speech acts across cultures, culturally-inflected conversation analysis, and the use of cultural frames. The third question is: How is culture co-constructed by participants in interaction? It discusses how applied linguistics has moved from a structuralist to a constructivist view of language and culture, from performance to performativity, and from a focus on culture to a focus on historicity and subjectivity. The fourth question is: How is research on language and culture affected by language technologies? The print culture of the book, the virtual culture of the Internet, the online culture of electronic exchanges all have their own ways of redrawing the boundaries of what may be said, written and done within a given discourse community. They are inextricably linked to issues of power and control. The last section explores the current methodological trends in the study of language and culture: the increased questioning and politicization of cultural reality, the increased interdisciplinary nature of research, the growing importance of reflexivity, and the noticeable convergence of intercultural communication studies and applied language studies in the study of language and culture.

Given the overwhelming diversity of areas covered by the field of research called "Applied Linguistics" (for a review, see Knapp 2014, de Bot in press) I will focus here on the area acknowledged by Knapp as "by far the biggest and best known", namely language studies or language education. The publication in 1998 of the 
little book Language and Culture (Kramsch 1998) in Henry Widdowson's Oxford Introductions to Language Study was a first attempt to stake out an area of Applied Linguistics focused specifically on the relation of language and culture. There had been before that several efforts to include "culture" in language education (see, e.g., Lado 1957; Crawford-Lange \& Lange 1984; Kramsch 1993; Seelye 1984) but culture was not a concept that resonated with scholars in second language acquisition/applied linguistics, who were more psycho- and sociolinguistically oriented and preferred to study language in its social or situational context (e.g., Selinker \& Douglas 1985). With the growing influence of anthropology and linguistic anthropology in particular, the concept of culture in Applied Linguistics began to shift from a stable national or social group entity to portable representations, and from products, beliefs and behaviors to processes of identification, symbolic power struggles and identity politics. Duranti and Goodwin Rethinking Context (1992), that appeared in the same decade as Scollon \& Scollon Intercultural Communication (1995), Gumperz and Levinson Rethinking Linguistic Relativity (1996), and Hanks Language and Communicative Practices (1996), served as inspiration to Kramsch (1993, 1998 and 2004).

By the end of the nineties, the modernist concept of culture was coming to be replaced by late modernist concepts like historicity and subjectivity, that put the focus on the historical and subjective nature of culture, conceived as co-constructed "membership in a discourse community that shares a common social space and history, and common imaginings. Even when they have left that community, its members may retain, wherever they are, a common system of standards for perceiving, believing, evaluating, and acting" (Kramsch 1998: 10). Such a definition suggests that the relation of language and culture has been studied from a variety of disciplinary and methodological perspectives. Linguists will ask the question: How are people's perceptions, beliefs, values encoded in the linguistic sign, i.e., how do the signs that people use reflect what people perceive, believe, what they are able to mean and the meanings they are able to communicate? Scholars in pragmatics will ask: How is cultural meaning constructed pragmatically by speakers in a communicative situation, i.e., how do they know how to evaluate the social situation in which they find themselves and act appropriately? Sociolinguists and linguistic anthropologists will ask: How is culture co-constructed by participants in interaction, i.e., how do they read one another and know how to play the social game? Literacy scholars will ask: How are language and culture affected by communication technologies, be they the pen and paper technology of print culture or the computer technology of virtual culture, i.e., to what extent is the medium itself the message and how does technology shape culture as it purports to merely transmit it? Critical discourse analysts will ask: How are traditional views of language and culture, including the definition given above, put into question nowadays 
by globalization, with its decentered, deterritorialized, decontextualized ways of positioning oneself, and of defining one's linguistic and cultural identity? Recent research in sociolinguistics, linguistic anthropology and cognitive science has enriched applied linguists' understanding of the relation of language and culture; it is enabling the field to ask new questions and find new research approaches to answer them.

This survey is organized around the aspects of language and culture mentioned above. It takes stock of the research questions and the research methods used then and now. Given the ill-defined boundaries between Applied Linguistics and Psycho- and Sociolinguistics and especially Linguistic Anthropology with regard to language and culture, it will not always be possible to distinguish research in applied linguistics from research done in these related fields. In the end I will consider some important analytical and methodological trends for the future.

\section{How is cultural meaning encoded in the linguistic sign?}

Taking language as cultural semiotic, this section considers the advances made in recent decades in three major areas that illuminate the way culture is encoded in the linguistic sign and its use: language and thought; language, cognition and emotion; and language and embodied knowledge. These areas of research fall roughly under the concept of language relativity.

Research on language relativity, that studies the way the language that people use shapes the way they think, has picked up since the nineties in Linguistic Anthropology with the work of Lucy (1992), Gumperz and Levinson (1996), Slobin (1996), and more recently Lera Boroditsky (2003) and Guy Deutscher (2010). While Whorf claimed that speakers were prisoners of the grammatical and lexical structures of their language this strong version of the linguistic relativity hypothesis has now been rejected and researchers tend to align more with Sapir's more moderate statement : "Language is a guide to social reality ... it powerfully conditions all our thinking about social problems and processes... The 'real world' is to a large extent unconsciously built up on the language habits of the group. No two languages are ever sufficiently similar to be considered as representing the same social reality. The world in which different societies live are distinct worlds, not merely the same world with different labels attached." (Sapir 1949: 68-69). This weaker version of the Sapir-Whorf hypothesis is now non-controversial (however, see McWhorter 2014 for a recent critique) and is researched in Applied Linguistics under three different aspects: semiotic relativity, linguistic relativity and discursive relativity (see Kramsch 2004). 
1.1 Semiotic relativity, or how the use of a symbolic system affects thought

This aspect of language relativity draws on the insights of Soviet psychologists like Lev Vygotsky . According to Vygotsky, a semiotic system is both linguistic sign and cognitive tool. By learning to speak and to communicate with others, children learn to think, by first internalizing the words and thoughts of others on the social plane, then making them their own on the psychological plane. According to Vygotsky and sociocultural theory (SCT), a community's culture and an individual's mind are in an inherently dialectical relationship as semiotically organized functional systems (Vygotsky 1978; Wertsch 1985). Lantolf (1999) describes the process of cultural acquisition in children as follows: "during ontogenesis the biologically specified mental endowment of children is shaped in specific ways once it interfaces with cultural forces as children are apprenticed into their native culture" (Lantolf 1999: 30). Cultural development here is taken to mean socialization into a given social group, be it the family, the school or the sportsteam.

In second language acquisition (SLA) research, the enthusiastic embrace of SCT by one of SLA's most prominent scholars, Merrill Swain, in the nineties (Swain 2000) constituted a sea change in the way SLA was conceived. Notions such as 'comprehensible input' (Krashen 1982), 'interaction and negotiation' (Long 1980) and 'comprehensible output' (Swain 1985), that had nothing to do with culture, gave way to concepts such as 'internal speech', 'zone of proximal development', 'scaffolding' and the 'help of more capable peers. This raised the possibility that children's speech and cognition were shaped by those of cultural others (Lantolf 2000; Lantolf \& Thorne 2006). The question arose then as to whether second language learners can appropriate for themselves the culture of the native speakers of that language (Lantolf 1999). As long as culture acquisition only means the ability to momentarily see the world through the eyes of a native speaker or to occasionally behave in ways that conform to native speaker expectations, culture acquisition should be a desirable goal of language learning. As Lantolf shows, language learners are able to adopt the conceptual metaphors of native speakers, for example, they can be taught to say in English "Thanks for your time", and "I want to respect your privacy". But they might have quite a different view of time and privacy from native English speakers. Indeed, if culture is, as Lantolf writes, drawing on Clifford Geertz, "an historically transmitted semiotic network constructed by humans and which allows them to develop, communicate, and perpetuate their knowledge, beliefs and attitudes about the world" (1999:30 my emphasis), then non-native speakers by definition cannot have this semiotic network transmitted to them historically since it is, as Geertz calls it, a "system of inherited conceptions" (Geertz 1973: 89). However, they can gain secondary access to it and make it their own in a manner that will be different from that of native speakers. 
Researchers in the SCT tradition have drawn on Vygotsky's work as well as on activity theory to develop more dialogic or dynamic ways of assessing learners' competences (Lantolf \& Poehner 2011) based on the difference between what a learner can do alone and what he/she can do with the assistance of others, and to design a task-based pedagogy in which learners cooperate on solving problems that mirror those encountered in real-world cross-cultural exchanges.

That SCT theory is now being put into question by the advent of complexity theory, a theory that is more in tune with our decentered, global world (see Sections 5.1, 5.2), shows how the theory of semiotic relativity itself is affected by larger sociocultural and sociopolitical forces like the collapse of the Soviet Union and globalization. If Vygotsky lived today in our hypersemioticized world of videogames, social networks, tweets, and 24/7 media outlets, he might have developed a different view of cognitive development. Not one based on the notion that "the mechanism of individual developmental change is rooted in society and culture" (Vygotsky 1978:7), but on the notion that individual development emerges in a non-linear way from much less stable and less predictable connections (Larsen-Freeman 1997) in a complex "network society" (Castells 1996, see Section 3.1 below).

With the growing importance of visual forms of communication and of research on multimodal semiotic systems (Gee 2014; Kress 2010), the interpenetration of the verbal and the non-verbal has created additional links between text and context, linguistic and visual forms of meaning making. Particularly online communication, that looks both at and through language, blurs the distinction between text and context in a complex virtual culture that creates additional layers of reality.

\subsection{Linguistic relativity, or how speakers of different languages think differently when speaking}

Linguistic relativity in language education has been researched from a psycholinguistic perspective by Slobin (1996) in his pathbreaking study of children's narratives, based on one story in pictures Frog where are you?, narrated by different children in their different native languages. Slobin argues that in order to speak at all, speakers must attend to the syntactic and lexical choices offered by their grammars, and that the cumulative occurrence of these choices can have cognitive and affective effects on the listener. For example, the obligation to attend to honorifics in Japanese or to T/V distinctions in German, French or Spanish, forces learners of these languages to pay attention to social hierarchies that they might not need to attend to in their mother tongue. Based on the typology of each of these languages, Slobin proposed to replace the Whorfian static nominal phrase 
"thought-and-language" with the more dynamic phrase "thinking-for-speaking", which moves culture from Whorf's focus on the linguistic sign to the activity of signing by living speakers and writers. Culture becomes indeed, as Brian Street suggested, a verb rather than a noun (Street 1993).

Recent psychological experimental research on linguistic relativity has further confirmed the influence of linguistic form on cognitive processes. For example, psychologists have explored whether and how the grammatical gender of inanimate objects influences speakers' associations. Speakers of Russian who have two words for "blue", siniy (light blue) and goluboy (deep blue) have a quicker reaction time when asked to identify kinds of blue than English speakers who only have one word for both (see Deutscher 2010:209, Boroditsky 2003). The recent discovery of a tribe of Australian Aborigines, the Guugu Yimithirr, that position themselves in space not according to the orientation of their bodies (right/left/in the front of/in the back of), but according to the four cardinal points of the compass (north/south/east/west) has triggered a flurry of studies on the cultural differences in people's conceptions of time and space (Haviland 1998).

Because linguistic relativity has recently attracted renewed attention from the popular media, there have been virulent debates about it. Responding to what Gopnik (2014:38) calls "pop Whorfianism", McWhorter (2014) argues that while the idea of linguistic relativity is clearly fascinating, it is, he says, plainly wrong. It is language that reflects culture and worldview, he argues, not the other way around. The fact that a language has only one word for eat, drink, and smoke, doesn't mean its speakers don't process the difference between food and beverage.

Since the eighties cognitive linguists like Lakoff (1987) and Lakoff \& Johnson (1980) have made cognitive science into a major approach to understanding the metaphoric structure of the mind and the close relationship of language, cognition and emotion (Wierzbicka 1992, Pavlenko 2005). Cultural signs can become idealized cognitive models or ICMs (Lakoff 1987) that channel our thinking and make it more difficult to grasp other people's words because of the different underlying ICMs associated with them. For example the prototypical ICM for "woman" will be different in Saudi Arabia and in the United States or between gays and heterosexuals. The linguists who separate cognition from morality and emotions have a noble belief in the rationality of human action. Surely we know what torture means!, Gopnik exclaims. If Cheney calls it enhanced interrogation, he argues, this still doesn't change the meaning of the word torture, which Cheney and the public know perfectly well. But cognitive linguists like Lakoff (1996) remind us that the public can be manipulated into believing that torture is "merely" an enhanced interrogation technique and thus does not protest. Indeed this is exactly what a marketing strategist like Frank Luntz (2007) manages to get corporations and political parties to do when he persuades them, for example, that calling the estate 
tax a "death tax" will lead citizens to vote against it, because, after all, it is not fair to tax people for dying. As citizens of our languages, we must be aware that words don't change meaning on their own; they can be made to change meaning in order to arouse different emotions and thus serve different political interests through discourse.

1.3 Discursive relativity, or how speakers of different discourses (across language or in the same language) have different cultural worldviews

As Scherzer remarked: "It is discourse that creates, recreates, focuses, modifies, and transmits both culture and language and their intersection (Scherzer, cited in Risager 2006:188). Speakers use the resources of discourse - contextualization cues (Gumperz 1982), indexicals, like affective and epistemic stance markers, speech acts and identity markers (Ochs 1996), and other communicative practices (Hanks 1996)- to link what they say to the larger context of culture. This link has been researched through discourse analysis of audio and, increasingly, video recordings of spontaneous interactions and their transcriptions. Advances in computer technology have enabled researchers to study the construction of culture in and through communicative exchanges in the minute details of gaze, posture, gestures and facial expressions (see Section 2).

Research in socialization studies, drawing on Bourdieu's notion of the habitus or embodied knowledge, has shown indexicality to be one of the major ways in which linguistic signs point to other signs to create a universe of meaning that can be shared by members of a speech community (Ochs 1996). But shareability or communicability brings with it several risks. First the sign, that following de Saussure might have been called "arbitrary" in its nature, becomes "motivated" in its use (Kress 2010), as communication entails intentionality, choice and expectation. Second, motivated signs can sediment or solidify through time to form condensation symbols (Sapir 1934) also called stereotypes. These condensation symbols appeal less to our rational apprehension of social reality than to our emotions and imagination. Sociolinguists have worked on the commodification of language and culture used for marketing and political purposes (Heller 2003); they have studied the keywords of neoliberal thought (Holborow 2012) and the use of multimodal signs (Kress 2010).

For example, Heller (2003) shows how the French language used in Quebec is now used as an exotic commodity that serves to sell French Canadian products on the global market. Holborow (2012) uses Raymond Williams' keywords, i.e. "ideologically sensitive words" (p.35) such as ideology, liberalism, folk, genius, citizenship, gender, to show how their associations and connotations change with the changing political, social and economic situation. She applies Williams' analysis 
to the current sloganization of political and academic life. Kress (2010) identifies three principles of sign-making: "1) that signs are motivated conjunctions of form and meaning; that conjunction is based on (2) the interest of the sign-maker; using (3) culturally available resources". (p. 10). He defines culture as follows: "Culture, in my use, is the domain of socially made values; tools; meanings; knowledge; resources of all kinds; society is the field of human (inter)action in groups; of 'work' or practices; of the use and effects of power" (p. 14). Heller, Holborow and Kress use a critical approach to discourse phenomena that links the motivated sign to cultural and political interest and power.

In sum, various fields of research related to Applied Linguistics have made it easier in recent decades to conceptualize how culture is encoded in the linguistic sign and its use. Culture is linked to language in three major ways: semiotically, linguistically, discursively. Language does not determine our cognition nor our emotions; torture means torture in any language. But by calling it something else, like "enhanced interrogation technique", one can change the degree of the cognition and the intensity of the emotion triggered by the words. Not in a deterministic way, and not in the dictionary meanings of words, but in the enunciative choices of speakers and writers and in the affective, social, and political meanings they assign to these words. It is to these enunciative choices that I now turn.

\section{How is cultural meaning expressed pragmatically through verbal action?}

In this section I focus on three emblematic studies: The cross-cultural speech act realization project (Blum-Kulka et al. 1989), Moerman's ethnographic conversation analysis (Moerman 1988), and Tannen's frame analysis (Tannen 1993) to discuss how applied linguistic research studied language and culture in the 80's and 90's. I will discuss in the next section the move toward a more constructivist approach (e.g., Cameron 1997) and a greater role given to performativity (Pennycook 2007, Ch.4).

\subsection{Cross-cultural speech act realization research}

The multinational cross-cultural speech act realization project (CCSARP) conducted by Blum-Kulka, House and Kasper in the eighties (Blum-Kulka et al. 1989) was a pathbreaking project that compared how requests and apologies were realized across different national languages and their national cultures. Discourse completion tests (DCT) and situational role-plays were used to elicit plausible rejoinders uttered by native speakers in distinct pragmatic situations, such as 
requesting that a roommate clean up the kitchen, or apologizing for not returning a book to your professor on time. This methodology was the object of frequent adjustments, first requesting an open-ended utterance, then providing a contextual constraint in the form of a third rejoinder. But still the DCT left too much to the imagination of the respondents and their idiosyncratic understandings of the situation to be able to provide a reliable measure of pragmatic competence pegged to "the native speaker".

\subsection{Culturally inflected conversation analysis}

As conversation analysis (CA) gained in importance in Applied Linguistics as a method to measure gains in grammatical and discourse competence (see Schegloff et al. 2002), the need was felt to incorporate a cultural dimension in a method that remained strictly focused on what the participants were orienting to in the conversation itself. Culture was brought into the picture by Moerman (1988), based on his work in Thailand and his memorable transcriptions of conversations between rice farmers and the local authorities. Moerman, who like Schegloff was based at UCLA, was the first applied linguist to include cultural and historical knowledge in the field of conversation analysis, that had been conceived by Schegloff as the pure study of the here-and-now turns at talk in conversation. Moerman's Talking Culture (1988) was largely rejected by pure CA analysts who refused to take into account anything that did not emerge from the analysis of the interaction/transcript itself, and they wouldn't consider culture as one such emergent category. However, Moerman's work enabled applied conversation analysts to include perceptions, memories, and cultural beliefs into their data as long as it could be shown that the participants were orienting to them at the time of utterance.

\subsection{Cultural frames}

The work of Deborah Tannen (e.g., 1984, 1993) was the third sociolinguistic influence on the way Applied Linguistics approached culture. In Framing in Discourse (1993), following the UC Berkeley tradition pioneered by Fillmore, Chafe, Gumperz, Ervin-Tripp and others, Tannen showed the importance of cultural frames to understand events. These "frames of expectation" were studied as social roles (e.g., what men and women expect of each other in conversation) or characteristics of a conversational style (e.g., California vs. New York Jewish style). Researchers gained access to these invisible frames by eliciting narratives from pictures or videos without words, such as Wallace Chafe's The Pear Story, that make visible a storyteller's assumptions about stories and their culturally-specific expectations about human motives and actions. Tannen found that, when they 
retold the pear story, her American informants paid much more attention to the cinematic aspects of the video than her Greek informants, who focused more on evaluating the motives and intentions of the characters and on passing moral judgments.

However, there were researchers who showed that such mappings of language on to culture were too simplistic and had to be studied with much greater differentiation. In her work on bilingualism, Ervin-Tripp, who had studied the different completions of the same story told by bilinguals in English and in Japanese to find out whether the differences were attributable to their different cultural backgrounds, had found that there was much more deviation between and within national groups than expected (Ervin-Tripp 1973).

Even the monolingual norms needed differentiating. Like many psychologists interested in bilingual children, Ervin-Tripp used a range of tests to measure the relation of language and culture in bilinguals, e.g., Thematic Apperception Tests, storytelling, word associations, sentence completions, semantic differentials and story completions. She studied the difference between foreign born Japanese of the first generation of immigrants to the U.S. (the Issei) and second generation Japanese-Americans (the Nisei) and their distance from American norms, distance from Japanese norms, and relative dominance of the two distance scores. She found that, when asked to give associations of words in Japanese, both Issei and Nisei gave associations typical of women in Japan; but when speaking English, the Issei gave typically American associations. For instance, Japanese women more often say "what I want most in life ... is peace". Americans say "... happiness" (p.69). But the Japanese responses were very much dependent on how long they had lived in the U.S., how many Anglo-American friends they had, whether they read American magazines, to what extent they kept the two cultures separate or not, and, ultimately, whether they could picture for themselves what a "typical" Japanese or American response would be. The over-all effect was that content shifted with language for both groups.

In sum, culture as enacted pragmatically by speakers and writers has been studied by psycho- and sociolinguists who have been quick to map the pragmatics of one language on to psychological and social characteristics of groups that speak that language. The dissatisfaction with such structuralist approaches to pragmatic cultural variation has prompted some researchers in recent years to turn to poststructuralist approaches that explore how language and culture co-construct each other in intercultural encounters. 


\section{How is culture co-constructed by participants in spoken interaction?}

If the main insight gained by research on language and culture in the 80's and 90's was that culture was expressed by participants in and through the very structure of spoken interaction, the post-structuralist turn in the last fifteen years has focused the attention on its co-constructed nature and on the non-structural aspects of this co-construction, such as identities, ideologies, timescales, and orders of indexicality.

\subsection{From structuralism to post-structuralism}

In the 80's and 90's, applied linguists were interested in finding out how interlocutors in conversation express social and cultural identities through their use of language in social contexts and how they reproduce well-bounded ethnic, familial, and social cultures. They drew, for example, on Gumperz' (1982) notion of contextualization cue and its role in cross-ethnic communication, on Ochs' study of family narratives and their role in reproducing a family culture of "fatherknows-best” (Ochs \& Taylor 1995), on Goffman's (1981) notion of facework and social positioning, and on Tannen's notion of conversational style (1984) in the reproduction of cultural networks. In the last 15 years, with globalization, applied linguists have had to deal with the multilingual uses of language in multicultural contexts and the co-construction of multiple, changing and sometimes conflictual cultural flows. They have explored the code-switching and code-meshing practices of bilingual youngsters in classrooms, in large urban centers and online exchanges (Canagarajah 2011), the transidiomatic practices of transnational immigrants (Jacquemet 2005; Lam 2009) and the rise of hyperreflexivity (Clark \& Dervin 2014) in an era of superdiversity. In so doing, they have broadened and diversified their research methodology.

For example, while Gumperz (1982) was intent in cataloguing the different types of codeswitching and in identifying their discrete pragmatic functions in countries which traditionally keep different linguistic codes strictly separated, Canagarajah (1993), studying the codeswitching in ESL classrooms in Sri Lanka, went beyond a structuralist typology. He recognized that, by allowing in the classroom code-switching and even code-meshing, i.e., the seamless blending of several languages as if they were one, the school was preparing the students for the hybrid culture of the real world outside, where such translanguaging is common currency (Garcia 2009). Going beyond Gumperz' typological interest, Canagarajah not only observed secondary school teachers in the classrooms but discussed the teacher's views on codeswitching after each lesson. He found that codeswitching fulfilled both microfunctions, such as classroom management and 
content transmission, and macrofunctions that dealt with socio-educational implications, such as the status of English as reserved for the formal content of the lesson and Tamil for personal and unofficial interactions. Thus he was able to draw inferences as to the emotional identification of the students with each of the languages: English perceived as impersonal, detached and alien; Tamil perceived as informal, personal and homely. By allowing codemeshing, the school was in effect allowing the students to appropriate and personalize English and integrate it into a post-structuralist hybrid culture of the future. However, in this post-structuralist culture people's identities are no longer unitary, stable and unproblematic, but multiple, changing, and more often than not the site of conflictual allegiances and memories (see Norton 2000).

Scholars like Canagarajah and those engaged in the study of English as a Lingua Franca (e.g., Seidlhofer 2011) would want to replace the outdated and even pernicious, because too deterministic, concept of culture with the much more agentive, fluid and hybrid notion of "cosmopolitan practice", in which interlocutors seek alignment, not intercultural understanding, multilayered affiliations, not unidimensional identities, and communicate with one another in the absence of any shared values. As Canagarajah argues: "Nothing may be shared in such communities other than the objectives that bring people together (e.g., professional, business, faith, etc.)... People come from their respective communities to negotiate their differences and find alignment by adopting constructive strategies" (2013:220). This cosmopolitan view of global citizenship does seem more suited to our mobile, decentered world, but it is a fallacy to think that it does away with culture. It has only replaced local culture as the negotiation of worldviews, attitudes and beliefs among families and friends with global culture as the negotiation of purposes and interests in joint professional, business, or faith projects. Indeed, one could say that in this new dispensation individuals share the value of negotiation and collaborative project management on a global scale and that is their "culture". In his latest book Communication Power (2009), the sociologist Manuel Castells, having defined culture as "the set of values and beliefs that inform, guide, and motivate people's behavior" (p. 36), distinguishes between global culture and local cultures as follows:

What characterizes the global network society is the contraposition between the logic of the global net and the affirmation of a multiplicity of local selves" (37)... The common culture of the global network society is a culture of protocols of communication enabling communication between different cultures on the basis not of shared values but of the sharing of the value of communication (p. $38 \mathrm{my}$ emphasis). 
Not surprisingly, speakers of English as a Lingua Franca favor this cosmopolitan view of culture, that befits English as the global language of business and technology and that gets constructed anew at every new global encounter. Such a view correlates well with a constructivist perspective on culture in interaction.

\subsection{Toward a constructivist view of language and culture in spoken interaction}

The turn from a structuralist to a post-structuralist approach to language and culture has been spearheaded by critical sociolinguists like Blommaert (2005), critical applied linguists like Pennycook (2007) and McNamara (2012), feminists like Cameron (2005) and proponents of a complexity theoretical approach to SLA like Larsen-Freeman (1997). For these researchers, culture is not a fixed, stable institutional reality that individuals belong to by virtue of having been socialized in it and that pre-exists the individual. Culture is, rather, a process of language use that is integrated with other semiotic systems such as "ritual, dance, music, graffiti, beat-boxing, clothing, gestures, posture, ways of walking and talking" (Pennycook 2007:75). Speakers and writers do not just perform culture, they construct it in interaction with others. In so doing, they often make use of the stereotypical views of traditional cultures, but in order to draw a profit of distinction and further their interests.

This constructivist view is inspired by the work of Michel Foucault. In his famous preface to the Order of Things (1970) Foucault recounts his inextinguishable laughter at reading Borges' story about a fictional Chinese encyclopedia that classifies animals according to a (for us) totally absurd system of classification such as: " a) belonging to the emperor, b) embalmed, c) tame, d) sucking pigs "etc. What we lack, Foucault says, to grasp the logic of this classification are the "fundamental codes of [the] culture" that guided the system of thought of the people living at the time. What we lack is an understanding of the conventions, presuppositions and norms of discourse that such a classification performs. Moreover, we fail to see the relation between this way of classifying animals and the classification of other phenomena, such as diseases, school children, citizens and historical events. A given culture is not only performed by its members in the form of such encyclopedias, but encyclopedias, like dictionaries, instruction manuals, examinations, child rearing practices and, today, social networking, are constantly creating and constructing the culture that people live by. 


\subsection{From performance to performativity}

Deborah Cameron has characterized this constructivist perspective as 'post-modern' (Cameron 2005), which doesn't mean that it has superseded the modern, but that the emphasis has shifted from an essentialist view of culture as the performance of pre-existing values and beliefs to a view of culture as a performative process in which old words can be given new meanings and can give birth to new thoughts. In her reanalysis of one of her students' work, Cameron (1997) gives a brilliant example of this performative turn in the study of language and culture, in this case the gendered culture of white males performing heterosexual masculinity by making fun of a colleague's homosexuality in his absence. The point of this exchange is not so much, Cameron argues, to bash gays, but, rather, to reconstruct their own heterosexual identity that might have been put into question by their association with a gay man. The notion of performativity serves here to analyze empirical data not as reflecting existing power relations but as creating and either reinforcing or transforming the balance of power between "men" and "women".

It is in this sense that we must read Judith Butler's argument in Excitable Speech. A politics of the performative (1997) about the linguistic vulnerability brought about by injurious speech. In her analysis of legal documents like "Don't Ask, Don't Tell", Butler shows how a culture of silence or of hate speech can wound by reactivating past contexts of discrimination into the present. But, she adds, because the performative can break with the past and be indeed transformative, it can "open up the domain of the sayable" and actually transform the meaning of, say, the word "queer" or "gay" from a term of insult to a marker of pride. Butler expands Austin's study of performatives into the more general notion of performativity that applies directly to the relation of language and culture. Quoting Toni Morrison, she writes: "We die. That may be the meaning of life. But we do language. That may be the measure of our lives.' (Butler 1997:7). Like Austin's performatives that do things with words, meaning making acts, both verbal and non-verbal, have a performative illocutionary force that not only performs but brings about social reality. In his analysis of popular hiphop culture, Pennycook has called such a performativity "a semiotic reconstruction" (2007:74). He writes: "This move from the performative to the transformative is crucial for our understanding of performativity as neither merely the playing out of public roles, nor the acting out of sedimented behavior, but the refashioning of futures" (p.77).

\subsection{From culture to historicity and subjectivity}

With performativity, time has re-entered the picture of a field that tended to consider culture only spatially or geographically. In anthropological research, the vague 
notion of 'culture' has given way to culture as historicity and subjectivity (Hanks 1996). Researchers, inspired by insights from complexity theory (Blommaert 2005; Larsen-Freeman 1997), cultural memory studies (Halbwachs 1992; Wertsch 2012), and metasemiotic studies (Silverstein 2004), look at the data with increased reflexivity and attention given to the subjective perspectives of both researcher and researched. For example, Kramsch and Whiteside (2008), using a complexity theory framework, examined the exchanges between Yucatec Maya immigrants and Asian shop owners in the Hispanic district of San Francisco and showed that, rather than performing expected linguistic and cultural identities, these immigrants operated on multiple timescales and positioned themselves subjectively in multiple ways so as to get along with others and avoid the police. Samata (2014), drawing from cultural memory theory, conducted interviews with immigrants to the UK who had no or limited knowledge of the language of their parents, but a strong affiliation with the culture of their parents' language. She too takes into account history and memory in her analyses and reflects on her own subject position as a multilingual and multicultural researcher. In his study of classroom discourse, Wortham (2006) draws on Silverstein's (1976) metasemiotic theory to illuminate the "metapragmatic models" or characteristic types of students and their actions and relationships to other students, that persist over the school year and influence how students perceive themselves and are perceived by others. They affect to a large extent what and how they learn the subject matter. These metapragmatic models of the self play a crucial role in the material construction of cultural meaning, i.e., in the repetitive or iterative suspension of time in the construction of social reality. Performative models of culture enable us to envisage another relation to time and space, one based not on linearity and simplistic views of causality, but on the emergence of phenomena nested one in the other, and on the "layered simultaneity" of timescales (Blommaert 2005, Ch.6) .

In sum: The performative turn in the study of language and culture within a post-structuralist perspective does not, as many have feared, transform culture into a merely discursive process, open to all the relativity and subjectivity of individuals' verbal utterances and with no clear agreed upon social boundaries. It does underscore the man-made nature of culture, its historicity, its disciplining power and its power to impose on a social group definitions of what is taken-for-normal, the shared understanding of people and events. But at the same time, the performative shows that the very political forces that have constructed culture can also be used to deconstruct and reconstruct culture in different ways. Performativity can indeed be seen as transformativity (Pennycook 2007:77). 


\section{How are language and culture affected by language technologies?}

In this section I consider the uses of literacies (written, print, online, multimodal) in shaping what we call culture. Literacy education and writing technology, inheritors of a print culture that started in the 16th century and that ever since has raised the interest of scholars in literacy issues such as genre, style, register, and norms of interpretation, has provided the foundation for applied linguists' understanding of language and culture (e.g., Kress 1996). Indeed, the structuralist approaches to language and language use discussed in previous sections of this paper come from an intellectual tradition steeped in print culture. For example, the very scholarly culture that enables applied linguists to transcribe spoken data and analyze and interpret them from a structuralist perspective belongs to an eminently literate culture that has academic legitimacy only to the extent that it is literate, not oral. Similarly, the application of Hallidayan systemic functional linguistics to teach register and genre (e.g., Cope \& Kalantzis 1993) and to reshape foreign language and literature curricula along genre-based principles (Byrnes \& Maxim 2004) is in line with an academic culture anxious to maintain the boundaries between oral and literate speech genres and their use. Such policing of literacy practices has been the hallmark of national cultures eager to use print technology to distinguish educated from less educated citizens, and to inculcate in the young the political and moral values that go along with such technology.

Enter online technology and the Internet. Applied Linguistics has been slow to research in any critical depth the effects of the new technology and its uses in language education (however, see Kern 2014; Kern \& Malinowski forthcoming; Kramsch 2009,Ch.6; Malinowski 2011, Malinowski \& Kramsch 2014). The pressure to prepare language learners for the "real" world of online communication has led most researchers to consider the computer as just another tool for the realization of print literacy goals, including the communicative competence that is taught in instructional environments. The virtual culture of computer-mediated communication has been viewed by many as the ideal instructional environment to implement the post-structuralist turn in the teaching of language and culture. This environment matches the communicative goals of language education: communication with native speakers, interaction with other non-native speakers, collaborative learning with more capable peers (Swain 2000), learner autonomy, and the learning through tasks that mirror those of the real world. All this at the click of a mouse. But the new environment also ushers in: a decentered view of the individual at the mercy of public opinion, distributed cognition and the danger of plagiarism, multiplicity of identities and a distinctly addictive reliance on the judgment of others, a blurring of oral and literate genres (e.g., email, Skype, blogs), and in general, a reshuffling of the usual axes of time, space, and reality (Kramsch 
2009,Ch.6; Kern \& Malinowski forthcoming). The very technology that promised to give all learners access to any foreign culture and its members is exacting its own price: shallow surfing of diversity instead of deep exploration of difference, leveling of aspirations and expectations, bullet-like ability to process information but loss of the ability to follow a complex argument, amazing ability to multitask but limited ability to problematize the task and question the question.

The political and ideological issues raised by each new technology, from print culture to multimodal forms of expression (Kress 2010) to the virtual culture of the Internet, have been addressed by Critical Discourse Analysis (CDA). I mentioned in the previous section the poststructuralist turn in Applied Linguistics, inspired by Foucault, that problematized culture by asking about the historic conditions of possibility of cultural phenomena, and the subject positions of the producers, reproducers and transformers of the discourses that constitute culture. In the same way as cultural theorists are rethinking concepts such as historical tradition and authenticity in an era of simulacrum and second life, so are critical applied linguists starting to question the authenticity of cultures in the age of the hyperreal and the virtual (e.g., Blommaert 2010). For this they need another kind of CDA than the one pioneered by Norman Fairclough (for a post-modern critique of Fairclough, see Blommaert 2005, Ch.2). They need to draw on complexity theory (e.g., Larsen-Freeman 1997; Morin 2005) and ecological approaches to language and culture (Kramsch 2002).

In Chapter 6 of his book Discourse. A critical introduction (2005) titled "History and Process", Blommaert recounts how, in preparation for a workshop on "Frame and Perspective in Discourse" held in the Netherlands on the 60th anniversary of the 1944 Warsaw Uprising, the participants had been handed the texts of various speeches made on the occasion and were asked to subject them to various forms of discourse analysis. Blommaert was able to show how the events themselves had been entextualized in different ways and how each of these texts was operating on various timescales: the time of the uprising itself, the time of the Allied invasion, the time of the Soviet restraint, as well as the present time in which most Western narratives follow the U.S. American interpretation, heavily tainted by a Cold War rhetoric that, as present events suggest, has not died down since the official end of the Cold War. All these timescales operate in what Blommaert calls "layered simultaneity" (p. 130). He writes:

We have to conceive of discourse as subject to layered simultaneity. It occurs in a real time, synchronic event, but it is simultaneously encapsulated in several layers of historicity, some of which are within the grasp of the participants, while others remain invisible, but are nevertheless present... People can speak from various positions on these scales. The synchronicity of discourse is an illusion that masks the densely layered historicity of discourse (pp. 130-131). 
Thus, while the actual workshop took place in 2004, the participants positioned themselves on different timescales, some more global, some more local, associated with different memories and anticipations of the future, within the various discourses surrounding the historical event called "the Warsaw uprising". This way of reading texts as entextualizations positioned on different timescales and in different orders of indexicality offer a more complex reading than traditional CDA and can serve as a model to analyze online texts with their equally complex relations to time, space and reality.

In sum: The relation of language and culture in Applied Linguistics is inseparable from the issues surrounding the use of language technologies. The print culture of the book, the virtual culture of the Internet, the online culture of electronic exchanges all have their own ways of redrawing the boundaries of what may be said, written and done within a given discourse community. They are inextricably linked to issues of power and control.

\section{Current methodological trends}

The last twenty years have seen the remarkable growth of fields related to Applied Linguistics, that all deal with language and culture: Communication Studies (in particular, Intercultural Communication); Linguistic Anthropology; Cognitive Science; Sociolinguistics. What are the unique insights from Applied Linguistics on the relation of language and culture?

\subsection{Increased politicization of the study of language and culture}

Under globalization, language education has to face two major challenges in its relation to culture. The first is political. Since the global crisis of capitalism in 2008, the increased competition for economic resources of all kinds, and the growing inequality around the world, culture wars have been exacerbated, and the symbolic power struggles have become more pronounced. As Holborow writes: "Ideology can be more usefully understood as a jigsawed, inconsistent representation which may find its expression in language but which is also distinct from it; it is a onesided set of ideas, articulated from the interests of a particular social class, which may be part believed and part rejected and whose degree of acceptance rests on its relationship to real-world events" (Holborow 2012:41). Applied linguists return to Volosinov's idea that "differently orientated accents intersect in every ideological sign. Sign becomes the arena of class struggle" (Volosinov, cited in Holborow 2012:37). Holborow stresses "the multiaccentuality of the ideological sign, and the sedimentation of different evaluative accents, which lie at the root of language 
change and of the generative nature of language itself" (p. 37). Following the idea that the linguistic sign not only represents and performs reality but constructs it as well, Hasan (2003) points to the semiotic struggle as to who will define and control reality itself. Research in language and culture increasingly consists of demystifying ideologies and giving a distinct political turn to social and cultural events.

In terms of methodology, we see applied linguists drawing on Critical Sociolinguistics and paying more attention to social and historical, transnational and global phenomena to explain the link between language and the larger cultural context (e.g., Blommaert 2010; Jacquemet 2005; Pennycook 2007), even when they deal with such educational issues as the learning and teaching of foreign languages (Kramsch 2014).

\subsection{Increased questioning of the very notion of cultural reality}

The Internet revolution has transformed the way symbolic systems define real, hyperreal and virtual cultures. While the real is still viewed as the domain of authentic, historically based cultural tradition, the hyper real of the Egyptian Sphinx and pyramids in Las Vegas, or the avatars of Second Life detach the real from its geographical place and make it into a culture beyond cultural reality. But virtual environments, like Facebook or Second Life, by recreating reality make it possible to question traditional culture. As the cultural geographer Nezar AlSayyad writes:

It is not that the real is being breached by the virtual. Rather, the virtual opens up multiple ways of engaging with the real by questioning, breaking, and negotiating realities. And therein lies the challenge to tradition. As the different virtual contexts we have examined, from Tiananmen Square to Second Life, create their own realities, the virtual enables us to develop a more sophisticated theory of the real (Al Sayyad 2014:217-8)

The virtual makes it possible to think that there are multiple forms of, as well as ways of engaging with, realities. The Tahrir Square revolution was not created by Facebook, but Facebook and other technologies gave people new ideas of what was possible.

In terms of methodology, applied linguists are starting to question the limitations of computer-mediated communication to achieve intercultural understanding. Telecollaboration, chatrooms, long-distance language learning, blogs, have undoubtedly increased the volume of verbal exchanges, and thereby facilitated the acquisition of linguistic structures, but it is not clear how the discourse of virtual exchanges gets translated into the increasingly diverse forms of communicative competence required nowadays on diverse levels of reality. Given the enormous pressure exerted by the computer industry on publishers and 
educators alike to use the new technologies in the classroom, applied linguists up to now have been more eager to justify the use of this technology than to explore its limitations. This is a wide open field of research begging to be further theorized and conceptualized.

\subsection{Increased interdisciplinarity}

We have seen the growing tendency among applied linguists to draw their theoretical inspiration from scholars not only in the social sciences but also in the physical and the human sciences, out of the need to take account of the multilingual, multimodal, global conditions in which language is learned and used. Ecological approaches have drawn on phenomenologists like Merleau-Ponty (Kramsch 2002), complexity theory has used concepts from dynamic systems theory ( Larsen-Freeman \& Cameron 2008), poststructuralist approaches have built on philosophers like Derrida, Foucault, and Butler (McNamara 2012). This has led to research questions that are broader than the positivistic, objective questions asked of the data in most of the social sciences. One of the methodological consequences of a poststructuralist approach to language and culture in Applied Linguistics (with its principles of emergence, its time scales, fractals, and nonlinear developments) is that fieldwork has to take place over longer periods of time (various local timescales) to analyze repeated acts (thickening) of identification (positionings) by others and self. For instance in Wortham 2006 one girl, Thyisha came to be identified as "outcast" and one boy, William as "unpromising boy" in a classroom over a whole academic year. The researcher was able to document the process by which metapragmatic models of the two students emerged and were constructed and solidified over time through repeated speech acts whose aggregate effects could not have been predicted.

Another methodological consequence of a poststructuralist approach to the study of language and culture is the more frequent use of literary works as sources of data. Language memoirs, novels, and autobiographies are being used to support the exploration of language learner subjectivities (e.g., Kramsch 2009; Pavlenko 2005). However, all these texts are studied either in English or in their English translation. The problem presented by multilingual literature, i.e., texts that codeswitch among various languages without necessarily providing any translation, is one that applied linguists have not yet explored, probably because most of them, even though they are more often than not bi- or multilingual, publish exclusively in English. But texts that systematically code-switch between many languages require, in order to capture their full cultural and emotional impact, a reader that is equally familiar with these languages. This in itself is a real world problem that still awaits serious applied linguistic research. 


\subsection{Growing importance of reflexivity}

With poststructuralism, greater importance has been given to reflexivity in research on language and culture in Applied Linguistics (Clark \& Dervin 2014). The kind of "participant objectivation" called for by Pierre Bourdieu in his reflexive brand of sociology (Bourdieu 2003) demands that researchers not only state their subject position, but embed their observations and analyses in their historical and subjective conditions of possibility. We are thus witnessing a historicization of research itself, away from sweeping universal claims and focused instead on the particular case study with potentially universal relevance. This brings Applied Linguistics closer, to paraphrase Clifford Geertz, to "what a critic does to illuminate a poem than what an astronomer does to account for a star." (1983:10). Hence, as mentioned above, the resurgence of interest in humanistic forms of inquiry, including narrative, as both a research tool and a pedagogic approach to the development of intercultural competence (Freadman 2014).

However, this increased reflexivity and focus on subjectivity does not mean that we should abandon efforts to think theoretically. Too many doctoral dissertations in Applied Linguistics, eager to collect and analyze data now made accessible through the new technologies, ignore the crucial role that theory plays in analyzing and interpreting these data. Without a theory of language as semiotic process (see Section 1), as social action (see Sections 2 and 3), or as complex phenomenon (see Section 5.3 above), for example, one cannot understand why a particular participant in a verbal exchange starts laughing, or feels the need to apologize, nor whether this is a cultural or a personal trait.

\subsection{Convergence between the field of Intercultural Communication Studies and Applied Linguistics}

Finally, the study of language and culture in Applied Linguistics must take into account the dramatic rise of the field of Intercultural Communication (ICC). Known first as "cross-cultural communication", this field was in the fifties affiliated with anthropology, then in the 80 's and 90s it became dominated by the comparative and positivist paradigms of cross-cultural psychology, in which culture is defined solely in terms of nationality and one culture is compared with another using some generalized constructs (e.g. Hofstede 1991; Triandis 1990). Despite the work of sociolinguists like Ron and Suzanne Scollon (1981) who used the term 'interethnic' to characterize cross-cultural communication between Athabaskan-Canadians and Anglo-Canadians, and despite their insistence that ICC had to do with culture as discourse (see their 1995 book Intercultural communication: A discourse approach), the field of Intercultural Communication has not until recently been concerned 
with language. However, in the last two decades, applied linguists have begun to bring ICC within the purview of Applied Linguistics . In foreign language learning and teaching, "intercultural learning" has become an influential approach to language education, based on the idea of "mediation between cultures", "personal engagement with diversity", and "interpersonal exchanges of meaning" (Liddicoat \& Scarino 2013:8). A special issue of Pragmatics edited by Meeuwis (1994) addressed the notion of culture and cultural difference. A new Routledge book series Language and Intercultural Communication features the work of applied linguists (Clark \& Dervin 2014; Dervin \& Risager 2014; Sharifian \& Jamarani 2013) and the Routledge journal Language and Intercultural Communication is hospitable to scholars from Applied Linguistics. In this respect, we note a convergence between the concerns of ICC studies and Applied Linguistics that can benefit both fields with regard to the study of language and culture.

\section{References}

Al Sayyad, N. 2014. Traditions: The Real, the Hyper, and the Virtual in the Built Environment. London: Routledge.

Blommaert, J. 2005. Discourse. Cambridge: CUP. DOI: 10.1017/CBO9780511610295

Blommaert, J. 2010. The Sociolinguistics of Globalization. Cambridge: CUP.

DOI: $10.1017 /$ CBO9780511845307

Blum-Kulka, S., House, J., Kasper, G. (eds). 1989. Cross-Cultural Pragmatics: Requests and Apologies [Advances in Discourse Processes XXXI], O.R. Freedle (ed.). Norwood NJ: Ablex.

Boroditsky, L. 2003. Linguistic relativity. In Encyclopedia of Cognitive Science, L. Nadel (ed.), 917-992. London: Macmillan.

Bourdieu, P. 2003. Participant objectivation. Journal of the Royal Anthropological Institute 9: 281-294. DOI: 10.1111/1467-9655.00150

Butler, J. 1997. Excitable Speech. The Politics of the Performative. New York NY: Routledge.

Byrnes, H. \& Maxim, H.H. (eds). 2004. Advanced Foreign Language Learning: A Challenge to College Programs. Boston MA: Heinle Thomson.

Cameron, D. 1997. Performing gender identity: Young men's talk and the construction of heterosexual identity. In Language and Masculinity, S. Johnson \& U. Meinhof (eds), 47-64. Oxford: Blackwell.

Cameron, D. 2005. Language, gender, and sexuality: Current issues and new directions. Applied Linguistics 26(4): 482-502. DOI: 10.1093/applin/ami027

Canagarajah, S. 1993. Critical ethnography of a Sri Lankan classroom: Ambiguities in student opposition to reproduction through ESOL. TESOL Quarterly 27(4): 601-626.

DOI: $10.2307 / 3587398$

Canagarajah, S. 2011. Code meshing in academic writing: Identifying teachable strategies of translanguaging. Modern Language Journal 95(3): 401-417.

DOI: $10.1111 / \mathrm{j} .1540-4781.2011 .01207 . x$

Canagarajah, S. 2013. From intercultural rhetoric to cosmopolitan practice: Addressing new challenges in Lingua Franca English. In Critical and Corpus-Based Approaches to 
Intercultural Rhetoric, D. Belcher \& G. Nelson (eds), 203-226. Ann Arbor MI: University of Michigan Press.

Castells, M. 1996. The Information Age: Economy, Society and Culture, Vol. I: The Rise of the Network Society, 2nd edn. Oxford: Blackwell.

Castells, M. 2009. Communication Power. Oxford: OUP.

Clark, J. \& Dervin, F. 2014. Reflexivity in Applied Linguistics. Language and Intercultural Education. London: Routledge

Cope, B. \& Kalantzis, M. (eds). 1993. The Powers of Literacy. A Genre Approach to Teaching Writing. Pittsburgh PA: Pittsburgh University Press.

Crawford-Lange, L. \& Lange, D. 1984. Doing the unthinkable in the second language classroom: A process for the integration of language and culture. In Teaching for Proficiency, the Organizing Principle [The ACTFL Foreign Language Education Series], T.V. Higgs (ed.), 139-177. Lincolnwood IL: National Textbook.

De Bot, K. In press. A Recent History of Applied Linguistics. London: Routledge.

Dervin, F. \& Risager, K. (ed.). 2014. Researching Identity and Interculturality. London: Routledge.

Deutscher, G. 2010. Through the Language Glass. Why the World Looks Different in Other Languages. New York NY: Metropolitan Books.

Duranti, A. \& Goodwin, C. (eds). 1992. Rethinking Context. Language as an Interactive Phenomenon. Cambridge: CUP.

Ervin-Tripp, S. 1973. An Issei learns English. In Language Acquisition and Communicative Choice. Essays by Susan M. Ervin-Tripp, selected and introduced by A.S. Dil, 62-77. Stanford CA: Stanford University Press.

Foucault, M. 1970. The Order of Things. New York NY: Vintage.

Freadman, A. 2014. Fragmented memory in a global age: The place of storytelling in modern language curricula. Modern Language Journal 98(1): 373-385.

DOI: $10.1111 / \mathrm{j} .1540-4781.2014 .12067 . \mathrm{x}$

Garcia, O. 2009. Bilingual Education in the 21st Century: Global Perspectives. Malden MA: Blackwell.

Gee, J.P. 2014. Unified Discourse Analysis: Language, Reality, Virtual Worlds and Video Games. London: Routledge.

Geertz, C. 1973. The Interpretation of Cultures. New York NY: Basic books

Geertz, C. 1983. Local Knowledge. Further Essays in Interpretive Anthropology. New York NY: Basic Books

Goffman, E. 1981. Forms of Talk. Cambridge MA: Harvard University Press.

Gopnik, A. 2014. Word magic. How much really gets lost in translation? The New Yorker, May $26,36-39$.

Gumperz, J.J. 1982. Discourse Strategies. Cambridge: CUP. DOI: 10.1017/CBO9780511611834

Gumperz, J. \& Levinson, S. (eds). 1996. Rethinking Linguistic Relativity. Cambridge: CUP.

Halbwachs, M. 1925[1992]. On Collective Memory. Chicago IL: University of Chicago Press.

Hanks, W. 1996. Language and Communicative Practices. Boulder CO: Westview Press.

Hasan, R. 2003. Globalisation, literacy and ideology. World Englishes 22(4): 433-448.

DOI: 10.1111/j.1467-971X.2003.00311.x

Haviland, J. 1998. Guugu Yimithirr cardinal directions. Ethos 26(1): 25-47. DOI: 10.1525/eth.1998.26.1.25

Heller, M. 2003. Globalization, the new economy and the commodification of language and identity. Journal of Sociolinguistics 74: 473-492. DOI: 10.1111/j.1467-9841.2003.00238.x

Hofstede, G. 1991. Cultures and organisations: Software of the mind. London: McGraw Hill. 
Holborow, M. 2012. Neoliberal keywords and the contradictions of an ideology. In Neoliberalism and Applied Linguistics, D. Block, J. Gray \& M. Holborow (eds), 33-55. London: Routledge. Jacquemet, M. 2005. Transidiomatic practices: Language and power in the age of globalization. Language \& Communication 25: 257-277. DOI: 10.1016/j.langcom.2005.05.001

Kern, R. 2014. Technology as pharmakon: The promise and perils of the Internet for foreign language education. Modern Language Journal 98: 330-347.

DOI: $10.1111 / \mathrm{j} .1540-4781.2014 .12065 . \mathrm{x}$

Kern, R. \& Malinowski, D. In press. Limitations and boundaries in language learning and technology. In Routledge Handbook on Language Learning and Technology, F. Farr \& L. Murray (eds). New York NY: Routledge.

Knapp, W. (ed.). 2014. Applications in applied linguistics. Modes and domains. AILA Review 26: 1-9. DOI: $10.1075 /$ aila.26.01kna

Kramsch, C. 1993. Context and Culture in Language Teaching. Oxford: OUP

Kramsch, C. 1998. Language and Culture. Oxford: OUP.

Kramsch, C. 2002. Introduction. How can we tell the dancer from the dance? In Language Acquisition and Language Socialization. Ecological Perspectives, C. Kramsch (ed.), 1-30. London: Continuum.

Kramsch, C. 2004. Language, thought and culture. In The Handbook of Applied Linguistics, A. Davies \& C. Elder (eds), 235-261. Oxford: Blackwell. DOI: 10.1002/9780470757000.ch9

Kramsch, C. 2009. The Multilingual Subject. Oxford: OUP.

Kramsch, C. 2014. Teaching foreign languages in an era of globalization: Introduction. Modern Language Journal 98(1): 296-311. DOI: 10.1111/j.1540-4781.2014.12057.x

Kramsch, C. \& Whiteside, A. 2008. Language ecology in multilingual settings. Towards a theory of symbolic competence. Applied Linguistics 29(4): 645-671. DOI: 10.1093/applin/amn022

Kramsch, C. \& Zhu, H. Forthcoming. Language and culture in English language teaching. In Routledge Handbook of English Language Teaching, G. Hall (ed.). London: Routledge.

Krashen, S. 1982. Principles and Practice in Second Language Acquisition. Oxford: OUP.

Kress, G. 1996. Before Writing. Rethinking the Paths to Literacy. London: Routledge.

Kress, G. 2010. Multimodality. A Social Semiotic Approach to Contemporary Communication. London: Routledge.

Lado, R. 1957. Linguistics across Cultures. Applied Linguistics for Language Teachers. Ann Arbor MI: University of Michigan Press.

Lakoff, G. 1987. Fire, Women, and Dangerous Things. Chicago IL: University of Chicago Press. DOI: 10.7208/chicago/9780226471013.001.0001

Lakoff, G. 1996. Moral Politics. What Conservatives Know that Liberals Don't. Chicago IL: University of Chicago Press.

Lakoff, G. \& Johnson, M. 1980. Metaphors We Live By. Chicago IL: University of Chicago Press. Lam, E.W.S. 2009. Multiliteracies on instant messaging in negotiating local, translocal, and transnational affiliations: A case of an adolescent immigrant. Reading Research Quarterly 44(4): 377-397. DOI: 10.1598/RRQ.44.4.5

Lantolf, J. 1999. Second culture acquisition: Cognitive considerations. In Culture in Second Language Teaching and Learning, E. Hinkel (ed.), 28-46. Cambridge: CUP.

Lantolf, J. 2000. Sociocultural Theory and Language Learning. Oxford: OUP.

Lantolf, J. \& Thorne, S. 2006. Sociocultural Theory and the Genesis of L2 Development. Oxford: OUP. 
Lantolf, J. \& Poehner, M.E. 2011. Dynamic assessment in the classroom: Vygotskyian praxis for second language development. Language Teaching Research 15(1): 11-33.

DOI: $10.1177 / 1362168810383328$

Larsen-Freeman, D. 1997. Chaos/complexity science and second language acquisition. Applied Linguistics 18(2): 140-165. DOI: 10.1093/applin/18.2.141

Larsen-Freeman, D. \& Cameron, L. 2008. Complex Systems and Applied Linguistics. Oxford: OUP.

Liddicoat, A. \& Scarino, A. 2013. Intercultural Language Teaching and Learning. Oxford: WileyBlackwell DOI: 10.1002/9781118482070

Long, M. 1980. Input, Interaction and Second Language Acquisition. PhD dissertation, UCLA.

Lucy, J. 1992. Language Diversity and Thought: A Reformulation of the Linguistic Relativity Hypothesis. Cambridge: CUP. DOI: 10.1017/CBO9780511620843

Luntz, F. 2007. Words that Work. It's not What You Say, It's What People Hear. New York NY: Hyperion.

Malinowski, D. 2011. Where is the Foreign? An Inquiry into Person, Place, and the Possibility of Dialogue in an Online French Language Class. PhD dissertation, Berkeley University.

Malinowski, D. \& Kramsch, C. 2014. The ambiguous world of heteroglossic computer-mediated language learning. In Heteroglossia as Practice and Pedagogy, A. Blackledge \& A. Creese, A. (eds), 155-178. Berlin: Springer. DOI: 10.1007/978-94-007-7856-6_9

McNamara, T. 2012. Poststructuralism and its challenges for applied linguistics. Applied Linguistics 33(5): 473-482. DOI: 10.1093/applin/ams055

McWhorter, J. 2014. The Language Hoax. Why the World Looks the Same in Any Language. London: Routledge.

Meeuwis, M. (ed.). 1994. Critical perspectives on intercultural communication. A special issue Pragmatics 4(3): 309-459.

Moerman, M. 1988. Talking Culture. Ethnography and Conversation Analysis. Philadelphia PA: University of Pennsylvania Press. DOI: 10.9783/9780812200355

Morin, E. 2005. Introduction à la Pensée Complexe. Paris: Points.

Norton, B. 2000. Identity and Language Learning. London: Longman.

Ochs, E. 1996 Linguistic resources for socializing humanity. In Rethinking Linguistic Relativity, J.J. Gumperz \& S. Levinson (eds.), 407-438. Cambridge: CUP.

Ochs, E. \& Taylor, C. 1995. The 'father-knows-best' dynamic in dinnertime narratives. In Gender Articulated. Language and the Socially Constructed Self, K. Hall \& M. Bucholtz (eds), 97120. London: Routledge.

Pavlenko, A. 2005. Emotions and Multilingualism. Cambridge: CUP.

DOI: $10.1017 /$ CBO9780511584305

Pennycook, A. 2007. Global Englishes and Transcultural Flows. London: Routledge.

Risager, K. 2006. Language and Culture Pedagogy: From a National to a Transnational Paradigm. Clevedon: Multilingual Matters.

Samata, S. 2014. Cultural Memory of Language. London: Bloomsbury Academic.

Sapir, E. 1934. Symbolism. In Encyclopaedia of the Social Sciences, 14, E. Seligman \& A.S. Johnson (eds), 492-495. New York NY: Macmillan.

Sapir, E. 1949. Selected Writings in Language, Culture and Personality, D. Mandelbaum (ed.). Berkeley CA: University of California Press.

Schegloff, E, Koshik, I., Jacoby, S. \& Olsher, D. 2002. Conversation analysis and applied linguistics. Annual Review of Applied Linguistics 22: 3-31. 
Scollon, R. \& Scollon, S. 1981. Narrative, Literacy and Face in Interethnic Communication. Norwood NJ: Ablex.

Scollon, R. \& Scollon, S. 1995. Intercultural Communication. A Discourse Approach. Oxford: Blackwell.

Seelye, N.H. 1984. Teaching Culture. Chicago IL: National Textbook Co.

Seidlhofer, B. 2011. Understanding English as a Lingua Franca. Oxford: OUP.

Selinker, L. \& Douglas, D. 1985. Wrestling with context in interlanguage theory. Applied Linguistics 6: 190-204 DOI: 10.1093/applin/6.2.190

Sharifian, F. \& Jamarani, M. (eds). 2013. Language and Intercultural Communication in the New Era. London: Routledge.

Silverstein, M. 1976. Shifters, linguistic categories, and cultural description. In Meaning in Anthropology, K. Basso \& H.A. Selby (eds), 11-55. Albuquerque NM: UNM Press.

Silverstein, M. 2004. 'Cultural' concepts and the language-culture nexus. Current Anthropology 45(5): 621-652. DOI: 10.1086/423971

Slobin, D. 1996. From 'thought and language' to 'thinking for speaking. In Rethinking Linguistic Relativity, J.J. Gumperz \& S. Levinson (eds), 70-97. Cambridge: CUP.

Street, B. 1993. Culture is a verb: Anthropological aspects of language and cultural process. In Language and Culture, D. Graddol, L. Thompson \& M. Byram (eds), 23-43. Clevedon: Multilingual Matters.

Swain, M. 1985. Communicative competence: Some roles of comprehensible input and comprehensible output in its development. In Input in Second Language Acquisition, S. Gass \& C. Madden (eds), 235-253. Rowley MA: Newbury House.

Swain, M. 2000. The output hypothesis and beyond: Mediating acquisition through collaborative dialogue. In Sociocultural Theory and Second Language Learning, J. Lantolf (ed.), 97114. Oxford: OUP.

Tannen, D. 1984. Conversational Style. Mahwah, NJ: Lawrence Erlbaum Associates.

Tannen, D. 1993. What's in a frame? In Framing in Discourse, D. Tannen (ed.), 14-56. Oxford: OUP.

Triandis, H.C. 1990. Cross-cultural studies of individualism and collectivism. In Cross-cultural Perspective, J.J. Berman (ed.), 41-33. Lincoln NE: University of Nebraska Press.

Vygotsky, L. 1978. Mind in Society. The Development of Higher Psychological Processes. Cambridge MA: Harvard University Press.

Wertsch, J. 1985. Vygotsky and the Social Formation of Mind. Cambridge MA: Harvard University Press.

Wertsch, J. 2012. Texts of memory and texts of history. L2 Journal 4(1): 9-20.

Wierzbicka, A. 1992. Semantics, Culture, and Cognition. Universal Human Concepts in Culturespecific Configurations. Oxford: OUP.

Wortham, S. 2006. Learning Identity. The Joint Emergence of Social Identification and Academic Learning. Cambridge: CUP.

\section{Author's address}

Ms. Claire Kramsch

1201 Shattuck Avenue

Berkeley, CA 94709

USA

ckramsch@berkeley.edu 